\title{
CAPITAL BUDGETING EVALUATION PRACTICES OF BUILDING CONIRACTORS IN HONG KONG
}

\author{
K. C. Lam, S.O. Cheung and C. M. Tang, City University of Hong Kong \\ S. T. Ng, University of Hong Kong
}

\section{INTRODUCTION}

Capital assets are used by the company in the physical process of producing goods and services and are ordinarily used for a number of years. The amounts involved are so large that businesses need to plan and evaluate expenditures for capital assets with care. The plan for expenditures is called a capital budget. The process of determining both how much to spend on a capital assets and which assets to acquire is called capital budgeting. Most firms prepare at least a short-run budget that indicates planned capital outlays for the current and near future periods. Many firms also prepare intermediate and long-term capital budgets that project capital requirements for three to five, and sometimes even ten years ahead. Capital budgets are based on sales forecasts and on the anticipated plant and equipment needed to meet those expected sales (Hunt and Terry, 1993).

Previous research studies on capital budgeting have mainly focused on the application and improvement of modelling techniques. For instance, Brealey and Myers (1991), Hassmann (1968), Van Horne (1980) and Weston and Brigham (1981) adopted operational research techniques to model the budgeting of capital finance. Other researchers proposed the use of mathematical and optimisation methods for capital budgeting (e.g. Aston, 1978; Bhaskar, 1978; J ennergren, 1990). While these modelling techniques are significant to the improvement of capital budgeting decision-making, relatively little research has been directed towards the behaviour of financial management within the construction industry, in particular the practices of capital budget evaluation used by contractors in different countries.

This paper examines the capital budget evaluation procedures used in the construction industry of Hong Kong (HK) in 1994 and 1999 (cf. Lam et al., 1994), and highlights the financial management behaviour in Hong Kong Construction industry and so provides a reference for contractors against which they can compare their behaviour. The paper consists of three sections: the sampling method, an analysis of capital budgeting evaluation practices and procedures, and the findings of a discriminant function analysis (DFA). The purposes of the DFA are to classify the financial management practices according to the peculiar characteristics of firms, and to establish the variables which have the greatest impacts on capital budgeting evaluation practices.

\section{METHODOLOGY}

Two hundred building engineering contractors out of 1000 (approx.) were randomly selected from the membership list of the Hong Kong Construction Association. Six contractors had changed address or gone bankrupt at the time of survey; the remaining 194 contractors were divided into three groups according to their size (maximum capacity) as defined by the HKSAR's Architectural Services Department. Classification was based on the total contract value that contractors are allowed to tender, i.e. Group A up to $\mathrm{HK} \$ 20$ million, Group B up to $\mathrm{HK} \$ 50$ million, and Group C having no upper limit.

The surveys were carried out by mail, followed by telephone contact. The questionnaire was modified from Pike's study (1988). In all 60 questionnaires were received, representing a response rate of $30.92 \%$. Group A had 19 responses out of 62 (30.65\%); Group B had 10 responses out of 48 (20.82\%) and Group C had 31 responses out of $84(36.90 \%)$. Although the number of responses from Group C contractors was higher than those from the other groups, the response rates across the three groups were very close, indicating that the results were not overly biased towards the large organisations.

Respondents were asked to rate the usage of the capital evaluation techniques, investment appraisal methods, risk analysis approaches and management science techniques. The rating was based on a fivepoint scale (i.e. $0=n o, 1=$ rare, 2=often, 
$3=$ mostly and $4=a /$ ways). To examine the popularity of these methods, the positive attitude (PA) was devised to represent the combined number of responses of rare, often, mostlyand always. Since the usage of a particular technique depends on the nature of decision being undertaken, some techniques might have been rarely or always used by a contractor. The PA therefore helps to distinguish between those contractors who did or did not use a particular technique at all. Besides the PA, the median (ME), mode (MO) and testing of null hypotheses were also considered to establish the extent of usage and the pattern of usage between the groups.

\section{CAPITAL BUDGETEVALUATION}

The literature shows that "searching and screening of alternatives", "financial evaluation", "risk analysis" and "best/worst estimate" are the most commonly used capital budget evaluation techniques in construction (Riggs, 1986). The findings of the current study concur with the literature. As shown in Table 1, the "searching and screening of alternatives" had the highest observed frequency of usage ( $\mathrm{PA}=96.6 \%$ ), followed by "financial evaluation"
(PA=93.1\%), "best/worst estimates" (PA=90.7\%), and "risk analysis" (PA=89.5\%).

\section{Searching and screening of alternatives}

An analysis of the median (Table 1 ) reveals that Groups A and C firms often adopt "searching and screening of alternatives" for capital budget evaluation $(\mathrm{Me}=2)$, while the usage of this technique by Group B was only rare $(\mathrm{Me}=1.00)$. The result of a nonparametric one-way ANOVA was 0.894 , supporting the null hypothesis that there were no significant differences between the three groups in the usage of this technique.

Financial evaluation

"Financial evaluation" was often used by small to large contractors ( $\mathrm{Me}=2$ for all three groups). In the large firms category, a high proportion of respondents mostly adopted "financial evaluation" technique $(\mathrm{Mo}=3)$, indicating that it is a very popular capital budget evaluation technique for contractors of that size. We uphold the null hypothesis of no difference between groups of firm (the three groups of firms showed similar interest in a "financial evaluation"), with the value of significance being 0.502 at $95 \%$ level of confidence.

Table 1: Comparisons of the usage of capital budget evaluation techniques

\begin{tabular}{|c|c|c|c|c|c|c|c|c|c|}
\hline Size of firm & \multicolumn{2}{|c|}{ Group A } & \multicolumn{2}{|c|}{ Group B } & \multicolumn{2}{|c|}{ Group C } & \multicolumn{3}{|c|}{ Overall } \\
\hline Firms have & Mo & $\mathrm{Me}$ & Mo & $\mathrm{Me}$ & Mo & $\mathrm{Me}$ & Mo & $\mathrm{Me}$ & $\begin{array}{l}\text { PA } \\
\text { (\%) }\end{array}$ \\
\hline $\begin{array}{l}\text { Searching and screening } \\
\text { of alternatives before } \\
\text { accepting projects }\end{array}$ & $\begin{array}{l}1.00 \\
n=22\end{array}$ & 2.00 & $\begin{array}{l}1.00 \\
n=9\end{array}$ & 1.00 & $\begin{array}{l}1.00 \\
n=27\end{array}$ & 2.00 & $\begin{array}{l}1.00 \\
\mathrm{n}=58\end{array}$ & 2.00 & 96.6 \\
\hline $\begin{array}{l}\text { Formal financial } \\
\text { evaluation }\end{array}$ & $\begin{array}{l}2.00 \\
n=22\end{array}$ & 2.00 & $\begin{array}{l}1.00 \\
n=9\end{array}$ & 2.00 & $\begin{array}{l}3.00 \\
n=27\end{array}$ & 2.00 & $\begin{array}{l}2.00 \\
n=58\end{array}$ & 2.00 & 93.1 \\
\hline Formal analysis of risk & $\begin{array}{l}1.00 \\
n=21\end{array}$ & 1.00 & $\begin{array}{l}2.00 \\
n=9\end{array}$ & 2.00 & $\begin{array}{l}1.00 \\
n=27\end{array}$ & 2.00 & $\begin{array}{l}1.00 \\
n=57\end{array}$ & 2.00 & 89.5 \\
\hline $\begin{array}{l}\text { Analysis under different } \\
\text { assumptions } \\
\text { (best/worst estimates) }\end{array}$ & $\begin{array}{l}2.00 \\
n=21\end{array}$ & 2.00 & $\begin{array}{l}2.00 \\
n=7\end{array}$ & 2.00 & $\begin{array}{l}2.00 \\
n=26\end{array}$ & 2.00 & $\begin{array}{l}2.00 \\
\mathrm{n}=56\end{array}$ & 2.00 & 90.7 \\
\hline
\end{tabular}

Number of cases $=60$ 


\section{Risk analysis}

Large and medium sized firms often undertook "risk analysis" (Me=2). Not too many small firms were keen on analysing their risks $(M e=1, M o=1$ ) although they are more prone to financial problems. A significance of 0.493 was found in the null hypothesis test, confirming that there were no differences between the groups in the use of the "risk analysis" technique for capital budget evaluation.

\section{Best/worst estimates}

An analysis of projects under different assumptions, i.e. "best/worst estimates", was often used by contractors of various sizes (Me $=2$ for all groups). This may be because the "best/worst estimate" is a relatively simple and quick process. The significance value was 0.509 , which was below the level corresponding to a $95 \%$ degree of confidence. The null hypothesis was rejected, and indicated that there are no significant differences in the application of this technique between the groups.

Despite the high PA values, it should be noted that the mode and median regarding the usage of the capital budget evaluation techniques discussed above were not particularly high in the current study. Some of these techniques involve sophisticated evaluation procedures and require a large amount of human resources. Contractors need to undergo a series of thorough investigations, discussions and evaluations prior to each investment, which may discourage some contractors in HK from adopting a proper capital budget evaluation technique.

\section{APPRAISAL TECHNIQUES}

Generally, after the cash flows have been estimated, firms evaluate their financial position to determine whether the investment should proceed. Several techniques are available to evaluate investment proposals. The popular investment appraisal methods namely "payback period" (PBP), "average accounting rate of return" (AARR), "internal rate of return" (IRR), and "net present value" (NPV) were used (Samuels, Willes and Brayshaw, 1991). Respondents were asked to rate their usage of the methods. As shown in Table 2, PBP was the most predominant investment appraisal technique used by practitioners $(\mathrm{PA}=86.4 \%)$, and this is in line with many previous similar studies (Kelly and Northcott, 1991; Klammer and Walker, 1984; Patterson, 1989; Pike, 1988). The AARR technique ranked second (PA=83.3\%). Although NPV has been argued as a popular technique for normative capital budgeting (Breadley and Myers, 1991; Horngern and Foster, 1991), NPV and IRR shared only an equal third ranking ( $\mathrm{PA}=69.0 \%)$.

Table 2: Comparisons of usage of investment appraisal techniques

\begin{tabular}{|l|c|c|c|c|c|c|c|c|c|}
\hline Size of Firm & \multicolumn{2}{|c|}{ Group A } & \multicolumn{2}{c|}{ Group B } & \multicolumn{2}{c|}{ Group C } & \multicolumn{3}{c|}{ Overall } \\
\hline $\begin{array}{l}\text { Appraisal techniques in } \\
\text { use }\end{array}$ & Mo & Me & Mo & Me & Mo & Me & Mo & Me & PA\% \\
\hline Payback period (PB) & $\begin{array}{l}2.00 \\
\mathrm{n}=22\end{array}$ & 1.50 & $\begin{array}{c}2.00 \\
\mathrm{n}=9\end{array}$ & 2.00 & $\begin{array}{c}2.00 \\
\mathrm{n}=28\end{array}$ & 2.00 & $\begin{array}{c}2.00 \\
\mathrm{n}=59\end{array}$ & 2.00 & 86.4 \\
\hline
\end{tabular}

Number of cases $=60$ 
The within group analysis reveals that there was not much difference for PBP and AARR. Large and medium contractors often used PBP and AARR for investment appraisal $(\mathrm{Me}=2, \mathrm{Mo}=2)$, while usage by small firms was between rare and often ( $\mathrm{Me}=1.5, \mathrm{Mo}=2$ ). All three groups of contractors indicated that they rare/yused NPV and IRR methods $(M e=1, M o=1)$. The median on the usage of IRR in Group B was zero (Me $=0$ ) indicating the some of these firms did not use IRR for appraising their investments.

\section{RISK ANALYSIS AND MANAGEMENT SCIENCE TECHNIQUES}

The techniques that managers might use for the evaluation of projects include risk analysis and management science techniques. There are several methods for analysing the riskiness of capital projects, and various management science techniques for evaluating or controlling projects. This section examines the usage of these methods by HK contractors.

\section{Risk analysis}

Every construction project is unique and each has different risk allocation, capital requirements, management teams, construction methods and sequences, and so on. All these factors could affect project price, and it is necessary to identify and analyse the risks associated with capital budget. Academic literature (Horngren and Foster, 1991; Pike, 1998) advocates that the evaluation of projects should account for different risk characteristics through various risk analysis techniques, such as "shortening payback period", "raising required rate of return", "probability analysis", "sensitivity analysis", and "beta analysis".

Table 3 shows the PAs of various risk analysis approaches. Their popularity in descending orders is "shortening payback period" (PA=88.3\%), "raising required rate of return" (PA=79.3), "probability analysis" (PA=75.4\%), "sensitivity analysis" (PA=64.9\%), and "beta analysis" (PA=48.2\%). More than half of the respondent $(51.8 \%)$ did not use "beta analysis" for risk analysis suggesting that this technique is not popular in $\mathrm{HK}$.

Table 3: Comparisons of usage of risk appraisal techniques

\begin{tabular}{|c|c|c|c|c|c|c|c|c|c|}
\hline Size of firm & \multicolumn{2}{|c|}{ Group A } & \multicolumn{2}{|c|}{ Group B } & \multicolumn{2}{|c|}{ Group C } & \multicolumn{3}{|c|}{ Overall } \\
\hline $\begin{array}{l}\text { Method in use for analysis } \\
\text { risk: }\end{array}$ & Mo & Me & Mo & $\mathrm{Me}$ & Mo & $\mathrm{Me}$ & Mo & $\mathrm{Me}$ & PA\% \\
\hline Shortening payback period & $\begin{array}{l}2.00 \\
n=22\end{array}$ & 2.00 & $\begin{array}{l}2.00 \\
n=9\end{array}$ & 2.00 & $\begin{array}{l}2.00 \\
n=29\end{array}$ & 2.00 & $\begin{array}{l}2.00 \\
n=60\end{array}$ & 2.00 & 88.3 \\
\hline \multicolumn{10}{|c|}{ One way ANOVA significance value $=0.757$} \\
\hline $\begin{array}{l}\text { Raising required rate of } \\
\text { return or discount rate }\end{array}$ & $\begin{array}{l}1.00 \\
n=22\end{array}$ & 1.50 & $\begin{array}{l}0.00 \\
n=9\end{array}$ & 2.00 & $\begin{array}{l}1.00 \\
n=29\end{array}$ & 1.00 & $\begin{array}{l}1.00 \\
n=60\end{array}$ & 1.00 & 79.3 \\
\hline \multicolumn{10}{|c|}{ One wayANOVA significance value $=0.688$} \\
\hline Probability analysis & $\begin{array}{l}1.00 \\
n=22\end{array}$ & 1.00 & $\begin{array}{l}0.00 \\
n=9\end{array}$ & 1.00 & $\begin{array}{l}1.00 \\
n=29\end{array}$ & 1.00 & $\begin{array}{l}1.00 \\
n=60\end{array}$ & 1.00 & 75.4 \\
\hline \multicolumn{10}{|c|}{ One- wayANOVA significance value $=0.026$} \\
\hline Sensitivity analysis & $\begin{array}{l}0.00 \\
n=22\end{array}$ & 1.00 & $\begin{array}{l}0.00 \\
n=9\end{array}$ & 0.00 & $\begin{array}{l}1.00 \\
n=29\end{array}$ & 1.00 & $\begin{array}{l}1.00 \\
n=60\end{array}$ & 1.00 & 64.9 \\
\hline \multicolumn{10}{|c|}{ One- way ANOVA significance value $=0.0004$} \\
\hline Beta analysis & $\begin{array}{l}0.00 \\
n=22\end{array}$ & 1.00 & $\begin{array}{l}0.00 \\
n=9\end{array}$ & 0.00 & $\begin{array}{l}0.00 \\
n=29\end{array}$ & 0.00 & $\begin{array}{l}0.00 \\
n=60\end{array}$ & 0.00 & 48.2 \\
\hline
\end{tabular}

Number of cases $=60$ 
The median and mode of "shortening payback period" was the highest ( $\mathrm{Me}=2.00$; $\mathrm{Mo}=2$ for all three groups) indicating that this technique was often used by contractors in analysing risks. The usage of "raising required rate of return" (Me=1 for large; $\mathrm{Me}=2$ for medium; $\mathrm{Me}=1$ for small), "probability analysis" (Me=1 for all groups), and "sensitivity analysis" (Me=1 for small and large; $\mathrm{Me}=0$ for medium) was rare. "Beta analysis" had the lowest median and mode ( $\mathrm{Me}=0 ; \mathrm{Mo}=0$ for medium and large groups).

According to the results of null hypothesis testing, only "sensitivity analysis" (significance $=0.0004$ ) and "probability analysis" (significance $=0.026$ ) were statistically significant. These methods showed strong correlations in the use of the techniques between groups.

\section{Management science techniques}

In accordance with the study, "planning programming" (e.g. critical path method, PERT) was the most commonly used management science technique in the construction industry (PA=87.3\%) (Table 4). A corporate cash flow can be obtained from the contract programme in conjunction with the resources, and the contract programme should preferably be in the form of a critical path in which early and late progress can be shown. In the process of planning, the contractor will follow the sequence and logic of the planning cycle to prepare his planning programme. With the logic and sequence of construction determined, a cumulative early-and-late progress envelope can be derived and converted into an early-and-late contract cash flow (Clough and Sears, 1991). The above procedures are common corporate cash flow forecasting methods. Many construction projects in HK are very complex, and the cash flow of these projects is likely to be influenced by the sequence of operations. It is normal that a high proportion of respondents uses "planning programming" as a technique for investment decision-making. The technique which ranked second is "mathematical programming" (PA=62.1\%), followed by "decision theory" (PA $57.9 \%)$ and "computer simulation" (PA $=55.9 \%)$.

A higher proportion of respondents in Groups B and C always use "planning programming" as a management science technique ( $\mathrm{Mo}=4$ for both groups; $\mathrm{Me}=3.5$ for medium firms and $\mathrm{Me}=3$ for large firms). In contrast, only Group A firms often use "planning programming" $\quad(\mathrm{Me}=2.00$; $\mathrm{Mo}=2.00$ ). The usage for other three management science techniques is rare $(\mathrm{Me}=1$ in virtually all cases).

Table 4: Comparisons of the usage of management science techniques

\begin{tabular}{|c|c|c|c|c|c|c|c|c|c|}
\hline Size of firm & & $p A$ & Gro & $p B$ & Gro & & & Overal & \\
\hline $\begin{array}{l}\text { Management science } \\
\text { techniques }\end{array}$ & Mo & $\mathrm{Me}$ & Mo & $\mathrm{Me}$ & Mo & $\mathrm{Me}$ & Mo & $\mathrm{Me}$ & PA\% \\
\hline $\begin{array}{l}\text { Mathematical } \\
\text { programming }\end{array}$ & $\begin{array}{l}0.00 \\
n=22\end{array}$ & 1.00 & $\begin{array}{l}0.00 \\
n=9\end{array}$ & 1.00 & $\begin{array}{l}1.00 \\
n=29\end{array}$ & 1.00 & $\begin{array}{l}0.00 \\
n=60\end{array}$ & 1.00 & 62.1 \\
\hline One way ANOVA signific & ce valu & $=0.954$ & & & & & & & \\
\hline Computer simulation & $\begin{array}{l}0.00 \\
n=22\end{array}$ & 1.00 & $\begin{array}{l}0.00 \\
n=9\end{array}$ & 0.00 & $\begin{array}{l}0.00 \\
n=29\end{array}$ & 1.00 & $\begin{array}{l}0.00 \\
n=60\end{array}$ & 1.00 & 55.9 \\
\hline One way ANOVA signific & ce valu & $=0.304$ & & & & & & & \\
\hline Decision theory & $\begin{array}{l}0.00 \\
n=22\end{array}$ & 1.00 & $\begin{array}{l}0.00 \\
n=9\end{array}$ & 2.00 & $\begin{array}{l}0.00 \\
n=29\end{array}$ & 1.00 & $\begin{array}{l}0.00 \\
n=60\end{array}$ & 1.00 & 57.9 \\
\hline One- way ANOVA signific & ce valu & 0.46 & & & & & & & \\
\hline Planning programming & $\begin{array}{l}2.00 \\
n=22\end{array}$ & 2.00 & $\begin{array}{l}4.00 \\
n=9\end{array}$ & 3.50 & $\begin{array}{l}4.00 \\
n=29\end{array}$ & 3.00 & $\begin{array}{l}2.00 \\
n=60\end{array}$ & 2.00 & 87.3 \\
\hline
\end{tabular}

Number of cases $=60$ 
Table 5: Comparisons of the usage of computer packages or financial modelling systems

\begin{tabular}{|l|c|c|c|c|c|c|c|c|c|}
\hline \multirow{2}{*}{ Size of firm } & \multicolumn{2}{|c|}{ Group A } & \multicolumn{2}{|c|}{ Group B } & \multicolumn{2}{c|}{ Group C } & \multicolumn{3}{|c|}{ Overall } \\
\cline { 2 - 9 } & Mo & Me & Mo & Me & Mo & Me & Mo & Me & PA\% \\
\hline Firms use of computer & 0.00 & 0.00 & 0.00 & 0.00 & 0.00 & 0.00 & 0.00 & 0.00 & 30 \\
package/ financial & $n=22$ & & $n=9$ & & $n=29$ & & $n=60$ & & \\
modelling: & & & & & & & & & \\
\hline
\end{tabular}

Number of cases $=60$

In the null hypothesis testing only "planning programme" is of statistical significance, with a value of 0.004 . The use of the four management science techniques was influenced by the size of the firms, with a bias towards usage by firms in Groups A and C.

\section{Computer packages or financial modelling systems for investment analysis}

Computer simulation packages are thought to be more realistic than theoretical calculations. However, the survey results indicate that the computer package is not very popular in capital financing ( $\mathrm{PA}=30 \%$ ) particularly for small (PA=27.3\%) and medium ( $P A=22.2 \%$ ) contractors (Table 5). In other words, over $70 \%$ of contracting firms in the various groups do not use computer various groups do not use computer modelling systems. The mode and median in all three groups are zero, indicating that an extremely low proportion of firms use computer modelling for capital budget evaluation.

The testing of the null hypothesis has a significance of 0.543 at $95 \%$ confidence level, and thus the null hypothesis is rejected. There is no association between groups in applying computer packages or financial models to investment analysis. This is not surprising considering the extra resources required for purchasing computer packages and/or financial modelling systems.

Table 6: Comparisons of the usage of methods for anticipating inflation

\begin{tabular}{|c|c|c|c|c|c|c|c|c|c|}
\hline Size of firm & \multicolumn{2}{|c|}{ Group A } & \multicolumn{2}{|c|}{ Group B } & \multicolumn{2}{|c|}{ Group C } & \multicolumn{3}{|c|}{ Overall } \\
\hline Firms which & Mo & $\mathrm{Me}$ & Mo & $\mathrm{Me}$ & Mo & $\mathrm{Me}$ & Mo & $\mathrm{Me}$ & PA\% \\
\hline $\begin{array}{l}\text { Consider inflation at risk } \\
\text { analysis/ sensitivity stage }\end{array}$ & $\begin{array}{l}1.00 \\
n=22\end{array}$ & 1.00 & $\begin{array}{l}2.00 \\
n=9\end{array}$ & 2.00 & $\begin{array}{l}1.00 \\
n=29\end{array}$ & 2.00 & $\begin{array}{l}1.00 \\
n=60\end{array}$ & 2.00 & 84.3 \\
\hline \multicolumn{10}{|c|}{ One way ANOVA significance value $=0.076$} \\
\hline $\begin{array}{l}\text { Specify cash flows in } \\
\text { constant process and } \\
\text { apply a real rate of return }\end{array}$ & $\begin{array}{l}2.00 \\
n=22\end{array}$ & 2.00 & $\begin{array}{l}0.00 \\
n=9\end{array}$ & 2.00 & $\begin{array}{l}2.00 \\
n=29\end{array}$ & 2.00 & $\begin{array}{l}2.00 \\
n=60\end{array}$ & 2.00 & 81.4 \\
\hline \multicolumn{10}{|c|}{ One- way ANOVA significance value $=0.826$} \\
\hline $\begin{array}{l}\text { Adjust for estimated } \\
\text { changes in general } \\
\text { inflation }\end{array}$ & $\begin{array}{l}2.00 \\
n=22\end{array}$ & 2.00 & $\begin{array}{l}2.00 \\
n=9\end{array}$ & 2.00 & $\begin{array}{l}2.00 \\
n=29\end{array}$ & 2.00 & $\begin{array}{l}2.00 \\
n=60\end{array}$ & 2.00 & 96.6 \\
\hline \multicolumn{10}{|c|}{ One way ANOVA significance value $=0.283$} \\
\hline $\begin{array}{l}\text { Specify different rates of } \\
\text { inflation for all costs and } \\
\text { revenues }\end{array}$ & $\begin{array}{l}2.00 \\
n=22\end{array}$ & 2.00 & $\begin{array}{l}2.00 \\
n=9\end{array}$ & 1.00 & $\begin{array}{l}1.00 \\
n=29\end{array}$ & 2.00 & $\begin{array}{l}2.00 \\
n=60\end{array}$ & 2.00 & 86.2 \\
\hline
\end{tabular}

Number of cases $=60$ 
Table 7: Comparisons of 1999 and 1994 surveys

\begin{tabular}{|c|c|c|c|c|c|c|}
\hline \multirow{2}{*}{$\begin{array}{l}\text { Year of study } \\
\text { Firms have }\end{array}$} & \multicolumn{2}{|c|}{1999} & \multicolumn{2}{|c|}{1994} & \multicolumn{2}{|c|}{ PA (\%) } \\
\hline & Mo & $\mathrm{Me}$ & Mo & $\mathrm{Me}$ & 1999 & 1994 \\
\hline \multicolumn{7}{|l|}{ Capital budget evaluation } \\
\hline $\begin{array}{l}\text { Searching and screening of } \\
\text { alternatives before accepting } \\
\text { projects }\end{array}$ & $\begin{array}{l}1.00 \\
n=27\end{array}$ & 2.00 & $\begin{array}{l}1.00 \\
n=29\end{array}$ & 2.00 & 96.3 & 96.6 \\
\hline Formal financial evaluation & $\begin{array}{l}3.00 \\
n=27\end{array}$ & 2.00 & $\begin{array}{l}4.00 \\
n=30\end{array}$ & 3.00 & 93.1 & 86.7 \\
\hline Formal analysis of risk & $\begin{array}{l}1.00 \\
n=27\end{array}$ & 2.00 & $\begin{array}{l}4.00 \\
n=29\end{array}$ & 2.00 & 89.5 & 96.6 \\
\hline $\begin{array}{l}\text { Analysis under different } \\
\text { assumptions } \\
\text { (best/worst estimates) }\end{array}$ & $\begin{array}{l}2.00 \\
n=27\end{array}$ & 2.00 & $\begin{array}{l}2.00 \\
n=29\end{array}$ & 2.00 & 90.7 & 75.9 \\
\hline \multicolumn{7}{|l|}{ Investment appraisal } \\
\hline Payback period (PB) & $\begin{array}{l}2.00 \\
n=28\end{array}$ & 2.00 & $\begin{array}{l}3.00 \\
n=30\end{array}$ & 3.00 & 89.3 & 86.7 \\
\hline $\begin{array}{l}\text { Average accounting rate of } \\
\text { return (AARR) }\end{array}$ & $\begin{array}{l}2.00 \\
n=29\end{array}$ & 2.00 & $\begin{array}{l}2.00 \\
n=29\end{array}$ & 2.00 & 93.1 & 86.2 \\
\hline Internal rate of return (IRR) & $\begin{array}{l}1.00 \\
n=27\end{array}$ & 1.00 & $\begin{array}{l}2.00 \\
n=29\end{array}$ & 2.00 & 89.7 & 82.8 \\
\hline Net present value (NPV) & $\begin{array}{l}1.00 \\
n=27\end{array}$ & 1.00 & $\begin{array}{l}2.00 \\
n=29\end{array}$ & 2.00 & 74.1 & 75.9 \\
\hline \multicolumn{7}{|l|}{ Risk analysis } \\
\hline Shortening payback period & $\begin{array}{l}2.00 \\
n=29\end{array}$ & 2.00 & $\begin{array}{l}2.00 \\
n=28\end{array}$ & 2.00 & 86.2 & 82.1 \\
\hline $\begin{array}{l}\text { Raising required rate of return or } \\
\text { discount rate }\end{array}$ & $\begin{array}{l}1.00 \\
n=29\end{array}$ & 1.00 & $\begin{array}{l}3.00 \\
n=29\end{array}$ & 2.00 & 74.1 & 86.2 \\
\hline Probability analysis & $\begin{array}{l}1.00 \\
n=29\end{array}$ & 1.00 & $\begin{array}{l}1.00 \\
n=27\end{array}$ & 1.00 & 81.5 & 74.1 \\
\hline Sensitivity analysis & $\begin{array}{l}1.00 \\
n=29\end{array}$ & 1.00 & $\begin{array}{l}1.00 \\
\mathrm{n}=27\end{array}$ & 1.00 & 81.5 & 77.8 \\
\hline Beta analysis & $\begin{array}{l}0.00 \\
n=29\end{array}$ & 0.00 & $\begin{array}{l}0.00 \\
n=26\end{array}$ & 1.00 & 48.1 & 57.7 \\
\hline \multicolumn{7}{|l|}{ Management science } \\
\hline Mathematical programming & $\begin{array}{l}1.00 \\
n=29\end{array}$ & 1.00 & $\begin{array}{l}0.00 \\
\mathrm{n}=29\end{array}$ & 1.00 & 66.7 & 72.4 \\
\hline Computer simulation & $\begin{array}{l}0.00 \\
n=29\end{array}$ & 1.00 & $\begin{array}{l}0.00 \\
n=29\end{array}$ & 1.00 & 40.7 & 65.5 \\
\hline Decision theory & $\begin{array}{l}0.00 \\
n=29\end{array}$ & 1.00 & $\begin{array}{l}0.00 \\
\mathrm{n}=30\end{array}$ & 2.00 & 51.9 & 66.7 \\
\hline Planning programming & $\begin{array}{l}4.00 \\
n=29\end{array}$ & 3.00 & $\begin{array}{l}3.00 \\
n=27\end{array}$ & 3.00 & 96.3 & 92.6 \\
\hline
\end{tabular}

Number of cases $=60$ 


\section{Inflation}

It is necessary to consider and anticipate inflation in capital budget planning. The most commonly used inflation anticipation methods were to "adjust for estimated changes in general inflation" (PA=96.6\%), "specify different rates of inflation for all costs and revenues" (PA=86.2\%), "consider inflation at risk analysis stage" (PA=84.3\%), and "specify cash flows in constant processes and apply a real rate of return" $(P A=81.4)$ (Table 6). Virtually all groups often use these four techniques for the forecast of inflation $(\mathrm{Me}=2)$. As for the significance tests, all variables are outside the $95 \%$ significance level therefore the null hypotheses for all four techniques were accepted. This suggests there is no significant association between the groups in considering the techniques for adjusting inflation in the investment decision.

\section{DISCUSSIONS - COMPARISON OF 1994 AND 1999 SURVEYS}

The results of the current study were compared with those of a similar survey conducted in 1994 (Lam et al., 1994) to determine if the capital budget evaluation practices as adopted by the HK contractors had remained consistent over the five year period. The comparisons indicate that more contractors became aware of the importance of capital budget evaluation, and the popularity and usage of certain capital budget evaluation techniques increased from 1994 to 1999.

\section{Capital budget evaluation}

A comparison of the PAs reveals that there was a general increase in the popularity of various capital budget evaluation techniques from 1994 to 1999 (Table 7), except for "risk analysis" (from $96.6 \%$ to $89.5 \%$ ). The most remarkable increase was the "best/worst estimate" (from 75.9\% to 90.7\%). However, when examining the mode, falling trends are noted in the extent of usage in some techniques. The drop in mode for "financial evaluation" was rather moderate (from $\mathrm{Mo}=4$ to $\mathrm{Mo}=3$ ), while there was a more significant drop in use of "risk analysis" (from $\mathrm{Mo}=4$ to $\mathrm{Mo}=1$ ).

\section{Appraisal techniques}

The PAs for the four investment appraisal techniques in the 1999 study were slightly higher than those of the 1994 study, except for NPV which dropped slightly from
$\mathrm{PA}=75.9 \%$ (1994) to $\mathrm{PA}=74.1 \%$ (1999). In terms of the extent of usage, there was a decrease in usage of PBP between 1994 and 1999 (from $\mathrm{Me}=3$ to $\mathrm{Me}=2$ ). This implies that smaller contracting firms in $\mathrm{HK}$ prefer to use the PBP technique (cf. Fremgen, 1973). In fact, PBP does have some disadvantages:

- cash flows outside the PBP are ignored when appraising an individual project

- both the post-payback returns and the distribution of returns within the PBP are ignored when used for comparing projects

- detailed information about the actual calculation of PBP is not provided.

Davis and Cosenza (1990) have suggested that the sophistication of PBP rules can be increased by setting minimum payback percentages at various points in time or using discounted returns.

\section{Risk analysis}

Comparing the results of the 1994 and 1999 studies shows that there were increases in the popularity of "shortening payback period" (from $\mathrm{PA}=82.1 \%$ to $\mathrm{PA}=86.2 \%$ ), "probability analysis" (from PA=74.1\% to $\mathrm{PA}=81.5 \%$ ), and "sensitivity analysis" (from $\mathrm{PA}=77.8 \%$ to $\mathrm{PA}=81.5 \%$ ). There was however a drop in the popularity of "raising required rate of return" (from $\mathrm{PA}=86.2 \%$ to $\mathrm{PA}=74.1 \%$ ) and "beta analysis" (from $\mathrm{PA}=57.7 \%$ to $\mathrm{PA}=48.1 \%$ ). The extent of usage of "raising required rate of return" dropped from $M e=2$ to $M e=1$, while for "beta analysis" the drop was from $\mathrm{Me}=1$ to $\mathrm{Me}=0$.

\section{Management science techniques}

The only technique which had a slight increase in its popularity was "planning programming" (from PA=92.6\% to PA=96.3\%). The popularity of the other three techniques diminished, especially for the computer simulation (a drop from $\mathrm{PA}=65.5 \%$ to $\mathrm{PA}=40.7 \%$ ). The high PA of "planning programming" indicates that HK contractors are by no means discounting the values of management science techniques. However, since the time and budget of construction projects are much tighter than before, contractors will direct their resources to those management science techniques which they are more familiar with and can rely on. In terms of the extent of usage, there was no particular improvement or decline in the use of different management science techniques between 1994 and 1999. 
DISCRIMINANT FUNCTION ANALYSIS

To further investigate the practices of capital budget evaluation, a discriminant function analysis (DFA) was employed to classify the firms according to a set of variables that best represent their characteristics (instead of grouping by size). DFA is a technique for deciding into which category a case (in this instance, a contractor) is most likely to fall. The "size of firm" was used as a variable for initial grouping, and Groups A, B and C were represented as Groups 1, 2 and 3 respectively in this analysis. The variables on capital budget evaluation, as examined in the above analyses, were used for the DFA.
The DFA generated two sets of standardised discriminant function coefficients ( $\lambda$ : Function 1 and Function 2, where the two functions represent two distinctive characteristics of contractors - see Table 8). Based on these two functions, it is possible to compute the discriminant scores for each case. As shown in Table 8, for Function 1, the variable having the greatest impact on capital budget evaluation was "net present value" (with an absolute of 1.426). This was followed by "internal rate of return" (1.252), "raising required rate of return" (1.250), and "specify different rates of inflation for all costs and revenues" (1.166).

Table 8: Standardised canonical discriminant function coefficients

\begin{tabular}{|l|c|c|}
\hline \multirow{2}{*}{ Variable criteria $(\theta)$} & \multicolumn{2}{|c|}{$\begin{array}{c}\text { Discriminant function } \\
\text { coefficients }(\lambda)\end{array}$} \\
\cline { 2 - 3 } & Function 1 & Function 2 \\
\hline Searching and screening of alternatives before accepting projects & -0.364 & -0.821 \\
\hline Formal financial evaluation & -0.131 & 0.788 \\
\hline Formal analysis of risk & 0.398 & 0.377 \\
\hline Analysis under different assumptions (best/worst estimate) & 0.003 & -0.091 \\
\hline Payback period & -0.032 & 0.480 \\
\hline Average accounting rate of return & 0.358 & 0.241 \\
\hline Internal rate of return & -1.252 & -0.298 \\
\hline Net present value & 1.426 & 0.251 \\
\hline Shortening payback period & 0.168 & -0.497 \\
\hline Raising required rate of return or discount rate & -1.250 & 0.373 \\
\hline Probability analysis & -0.030 & 0.192 \\
\hline Sensitivity analysis & 0.748 & 0.224 \\
\hline Beta analysis & 1.091 & -1.150 \\
\hline Mathematical programming & -0.531 & -0.070 \\
\hline Computer simulation & 0.487 & 0.027 \\
\hline Decision theory & -0.725 & -0.533 \\
\hline Planning programme & 1.101 & -0.118 \\
\hline Consider inflation at risk analysis/sensitivity stage & 0.103 & 0.567 \\
\hline Specify cash flows in constant process and applya real rate of return & -0.269 & 0.375 \\
\hline Adjust for estimated changes in general inflation & 0.384 & -0.443 \\
\hline Specify different rates of inflation for all costs and revenues & -1.166 & 0.754 \\
\hline $\begin{array}{l}\text { Computer package or financial modelling system used for } \\
\text { investment analysis }\end{array}$ & 0.475 & -0.272 \\
\hline & & \\
\hline
\end{tabular}


The group centroids (i.e. group means) of the three groups are summarised in Table 9. For Function 1, Group 1 had a mean of -1.770 , while the means for Groups 2 and 3 were +1.455 and +1.160 respectively, indicating that the characteristics of Group 1 are opposite to Groups 2 and 3. The attitudes of Group 1 contractors on the usage of "net present value", "internal rate of return", "raising required rate of return", etc. were distinct from those of Group 2 and 3 contractors. For Function 2, the mean for Group 2 was in negative territory (-2.342), while the means for Groups 1 and 3 were positive (+0.007 and +0.673 respectively). A territorial map showing the centroid and borders of each Group within Functions 1 and 2 is shown in Figure 1.
The DFA also generated classification results. This includes a predicted group membership, which represents an expected classification of the different cases. The measure is evaluated by comparing the observed misclassification rate to that expected by chance alone. The percentage of cases correctly classified can be regarded as a measure of effectiveness of the discriminant function. As shown in Table 10, $89.9 \%$ of all cases were correctly classified, i.e. only $10.2 \%$ of the cases (overall) were misclassified. The group breakdowns indicate that $90.0 \%$ of cases in Group 1, 83.3\% of cases in Group 2, and $91.3 \%$ of cases in Group 3 were correctly classified and predicted.

Table 9: Canonical discriminant functions evaluated at group centroids (group means)

\begin{tabular}{|c|c|c|}
\hline \multirow{2}{*}{ Group } & Discriminant score & Discriminant score \\
\cline { 2 - 3 } & Function 1 & Function 2 \\
\hline 1 & -1.770 & 0.007 \\
\hline 2 & 1.455 & -2.342 \\
\hline 3 & 1.160 & 0.673 \\
\hline
\end{tabular}

Figure 1: Scatterpl ot of canonical discriminant functions for all groups

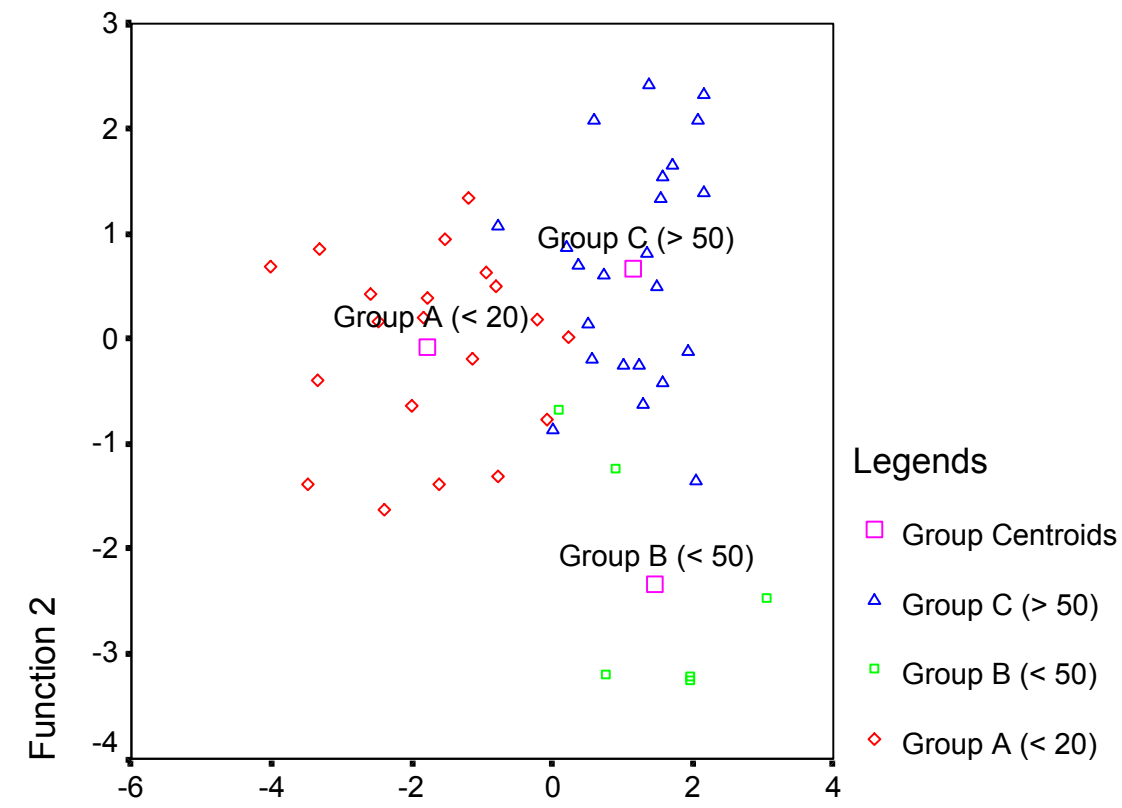

Function 1 
Table 10: Table of classification results from the discriminant function analysis

\begin{tabular}{|c|c|c|c|c|c|}
\hline \multirow{2}{*}{\multicolumn{2}{|c|}{$\begin{array}{l}\text { Actual group } \\
\text { (classified by size of firm) }\end{array}$}} & \multirow{3}{*}{$\begin{array}{c}\text { Number } \\
\text { of cases }\end{array}$} & \multicolumn{3}{|c|}{ Predicted group membership } \\
\hline & & & 1 & 2 & 3 \\
\hline Group A (<20 M) & 1 & & $\begin{array}{c}18 \\
90.0 \%\end{array}$ & $\begin{array}{c}0 \\
0.0 \%\end{array}$ & $\begin{array}{c}2 \\
10.0 \%\end{array}$ \\
\hline Group B (<50 M) & 2 & 6 & $\begin{array}{c}0 \\
0.0 \%\end{array}$ & $\begin{array}{c}5 \\
83.3 \%\end{array}$ & $\begin{array}{c}1 \\
16.7 \%\end{array}$ \\
\hline Group C (> 50 M) & 3 & 23 & $\begin{array}{c}1 \\
4.3 \%\end{array}$ & $\begin{array}{c}1 \\
4.3 \%\end{array}$ & $\begin{array}{c}21 \\
91.3 \%\end{array}$ \\
\hline
\end{tabular}

Since the performance of a contractor's financial management may not be easily represented by its size, the purpose of DFA is to identify a set of variables (Table 8) which could help in scrutinizing the performance of a firm in capital budgeting. The variables used in this analysis are the primary factors involved in managing capital budgets, and these variables are highly correlated with the firms' competence in managing their finances. Based on this analysis, contracting firms can be classified in accordance with their level of performance in managing the capital budgeting process.

\section{CONCLUSION}

This paper reports a study on the capital budget evaluation techniques used by building contractors in HK. The majority of firms studied employed some forms of evaluation techniques for investigating project finance. The most popular capital budget evaluation technique were "searching and screening of alternatives" and "financial evaluation", while PBP and AARR were considered as the most popular appraisal techniques. The findings are different from the standard literature, which argues that NPV and IRR are the predominant techniques for capital budgeting.

Risk analysis is very important in decisionmaking as risks may exist in any prospective investments. Many firms undertook a formal risk analysis, with the most commonly used technique being "shortening payback period" and "raising required rate of return". Less than half of the respondents used "beta analysis", indicating the unpopularity of this technique in HK.

With the rapid development in computer technology, many techniques in capital budgeting have been computerised. Most firms, however, still rely on "planning programming", such as critical path analysis or PERT, rather than using computer simulations. This may be due to cost burdens imposed by additional equipment and specialists. Although computerisation was not particularly popular in HK, most contractors agreed that a systematic and highly developed capital budgeting system was important in making sound investment decisions.

A comparison of the 1994 and 1999 studies reveals that there is a general increase in the popularity in the usage of capital budget evaluation techniques. The most remarkable increase in popularity included the "best/worst estimate", "financial evaluation", AARR, IRR, and "probabilistic analysis". Despite the conservative nature of the construction industry in $\mathrm{HK}$, construction companies are aware of the importance of financial management and now apply a greater variety of techniques in capital budget evaluation. There was, however, a significant drop in the popularity of "computer simulation" between 1994 and 1999, highlighting a need to examine why HK contractors are moving away from the use of the computer as a decision aid for financial management.

This survey carried out for this study limits any generalisation of findings to those of the construction finance practices of HK contractors. However, the survey helps to ensure that the results can accurately reflect the perceptions of respondents in HK. This makes the work valuable in terms of adding to the knowledge of contemporary practice, and identifying issues which may shape and direct in the future. 


\section{Acknowledgements}

The work described in this paper was partially supported by a grant from the Research Grant Council of the Hong Kong Special Administrative Region, China (Project No. 9040593). The authors would like to thank Professor Richard Pike for kindly permitting his questionnaires to be adapted for use in this survey. Sincere thanks are extended to all contracting firms in HK who participated in the two surveys.

\section{REFERENCES}

Ashton, D.J . (1978) The construction and use of mathematical programming models for the analysis of the integrated investment and financial decision within a firm. Unpublished PhD thesis, University of Warwick.

Bhaskar, K.N. (1978) Linear programming and capital budgeting: the financial problem, J ournal of Business Finance and Accounting, 5 (2), Spring, 159-194.

Brealey, R.A. and Myers, S.C. (1991) Principles of corporate finance, 4th Edition. McGraw-Hill Inc.

Clough, R. H. and Sears, G. A. (1991) Construction Project Management, 3rd Edition. Wiley, New York.

Davis, D. and Cosenza, R.M. (1990) Business research for decision making. PWS-KENT Publishing Company.

Fremgen, J.M. (1973) Capital budgeting practices: a survey. Management Accounting, May, 19-25.

Hanssmann, F. (1968) Operational research techniques for capital investment, J ohn Wiley and Sons, New York.

Horngren, C.T. and Foster, G. (1991) Cost accounting: a managerial emphasis, 7th Edition. Prentice-Hall, Englewood Cliffs, N.J .

Hunt, B. and Terry, C. (1993) Financial Instruments and Markets, $2^{\text {nd }}$ Edition. Thomas Nelson, Australia.

J ennergren, L.P. (1990) Valuation by linear programming - a pedagogical note. J ournal of Business Finance and Accounting, 17 (5), Winter, 751-756.

Kelly, M. and Northcott, D. (1991) Divergence of management accounting practices from theory: some observations based on a field study. Accounting Forum, September, 44-80.
Klammer, T.D. and Walker, M.C. (1984) The continuing increase in the use of sophisticated capital budgeting techniques. The California Management Review, 33 (3), Spring, 756.

Lam, K.C., Tam, C.M. and So, A.T.P. (1994) A survey of capital budgeting techniques used by contracting firm in Hong Kong. In: Proceedings: 1st International Conference Changing Role of Contractors in Asia Pacific Rim, Chartered Institute of Building, May, 281-287.

Patterson, C.S. (1989) Investment decision criteria used by listed New Zealand companies. Australian J ournal of Management, 27 (1), December, 59-69.

Pike, R.H. (1988) An empirical study of the adoption of sophisticated capital budgeting practices and decision-making effectiveness. Accounting and Business Research, 18 (72), Autumn, 341-351.

Riggs, L. S. (1986) Cost and Schedule Control Techniques in Industrial Construction. A Report to the Construction Industry Institute, University of Texas at Austin.

Samuels, J.M., Willes, F.M. and Brayshaw, R.E. (1991) Management of firm finance, 5th Edition. Chapman and Hall.

Van Horne, V.C. (1980) Financial management and policy, 5th Edition. Prentice Hall, Englewood Cliffs, N. J .

Weston, J.F. and Brigham, E.F. (1981) Managerial finance, 7th Edition., Dryden Press, Hinsdale, III. 
Appendix I: Positive Attitudes of Respondents for Variables

\begin{tabular}{|c|c|c|c|c|}
\hline Variable & $\begin{array}{l}\text { Group A } \\
(<20 \mathrm{M})\end{array}$ & $\begin{array}{l}\text { Group B } \\
(<50 \mathrm{M})\end{array}$ & $\begin{array}{l}\text { Group C } \\
(>50 \mathrm{M})\end{array}$ & Over all \\
\hline $\begin{array}{l}\text { A specific research for and screening of alternatives } \\
\text { before accepting projects }\end{array}$ & $100.0 \%$ & $100.0 \%$ & $92.6 \%$ & $96.4 \%$ \\
\hline A formal financial evaluation & $100.0 \%$ & $88.9 \%$ & $88.9 \%$ & $93.1 \%$ \\
\hline A formal analysis of risk & $81.0 \%$ & $100.0 \%$ & $92.6 \%$ & $89.5 \%$ \\
\hline $\begin{array}{l}\text { Analysis under different assumption (best and worst } \\
\text { estimates) }\end{array}$ & $95.2 \%$ & $85.7 \%$ & $88.5 \%$ & $90.7 \%$ \\
\hline Payback period & $81.8 \%$ & $88.9 \%$ & $89.3 \%$ & $86.4 \%$ \\
\hline Average accounting rate of return & $77.3 \%$ & $66.7 \%$ & $93.1 \%$ & $83.3 \%$ \\
\hline Discounting internal rate of return & $68.2 \%$ & $66.7 \%$ & $70.4 \%$ & $69.0 \%$ \\
\hline Discounting net present value & $63.6 \%$ & $66.7 \%$ & $74.1 \%$ & $69.0 \%$ \\
\hline Shorten payback period & $90.9 \%$ & $88.9 \%$ & $86.2 \%$ & $88.3 \%$ \\
\hline Raising required return or discount rate & $90.9 \%$ & $66.7 \%$ & $74.1 \%$ & $79.3 \%$ \\
\hline Probability analysis & $72.7 \%$ & $62.5 \%$ & $81.5 \%$ & $75.4 \%$ \\
\hline Sensitivity analysis & $54.5 \%$ & $37.5 \%$ & $81.5 \%$ & $64.9 \%$ \\
\hline Beta analysis & $52.4 \%$ & $37.5 \%$ & $48.1 \%$ & $48.2 \%$ \\
\hline Mathematical programming & $54.5 \%$ & $66.7 \%$ & $66.7 \%$ & $62.1 \%$ \\
\hline Computer simulation & $54.5 \%$ & $44.4 \%$ & $60.7 \%$ & $55.9 \%$ \\
\hline Decision theory & $63.7 \%$ & $62.5 \%$ & $51.9 \%$ & $57.9 \%$ \\
\hline Planning programme & $77.3 \%$ & $83.3 \%$ & $96.3 \%$ & $87.3 \%$ \\
\hline Consider at risk analysis/sensitivity stage & $81.8 \%$ & $66.7 \%$ & $92.9 \%$ & $84.7 \%$ \\
\hline $\begin{array}{l}\text { Specific cash flow in constant process and applya } \\
\text { real rate of return }\end{array}$ & $77.3 \%$ & $66.7 \%$ & $89.3 \%$ & $81.4 \%$ \\
\hline Adjust for estimated changes in general inflation & $95.5 \%$ & $88.9 \%$ & $100 \%$ & $96.6 \%$ \\
\hline $\begin{array}{l}\text { Specific different rates of inflation for all costs and } \\
\text { revenues }\end{array}$ & $90.9 \%$ & $66.7 \%$ & $88.9 \%$ & $86.2 \%$ \\
\hline $\begin{array}{l}\text { Computer package or financial modelling system } \\
\text { used for investment analysis }\end{array}$ & $27.3 \%$ & $22.2 \%$ & $34.5 \%$ & $30 \%$ \\
\hline
\end{tabular}

